\title{
MULTIKULTURALISME MEMBANGKITKAN PERSATUAN DAN KESATUAN NKRI
}

\author{
Dinasti Ayu Tunggal Dewi \\ Institut IImu Kesehatan Surya Mitra Husada \\ dinastiayu17@gmail.com
}

\begin{abstract}
Abstrak
Multikulturalisme memiliki dampak positif dan negatif. Dampak positifnya bisa mengukuhkan persatuan, sementara dampak negatifnya bisa menyebabkan perpecahan. Salah satu masalah yang ada di masyarakat terkait dengan multikulturalisme adalah konflik yang disebabkan oleh etnosentrisme yang dapat memecah persatuan dan kesatuan dalam masyarakat. Oleh karena itu dibutuhkan semangat multikulturalisme, yaitu bagaimana kelompok-kelompok etnik semestinya memposisikan dirinya ke dalam sebuah kehidupan bersama dalam sebuah masyarakat nasional yang dikelilingi oleh nilai-nilai universal, seperti: demokrasi, keadilan, persatuan, dan kemanusiaan.Salah satu usaha untuk menjaga keharmonisan multikulturalisme adalah melakukan sosialisasi atau pembinaan kepada masyarakat tentang pentingnya menjaga keserasian antara berbagai suku bangsa. Pembinaan kepada masyarakat dapat dilakukan dengan sosialisasi langsung kepada masyarakatumum maupun melalui pendidikan di sekolah, khususnya kepada generasi muda bangsa.
\end{abstract}

Kata Kunci: Multikulturalisme, Persatuan, Kesatuan

\section{Latar belakang}

Indonesia sebagai negara multikultural memiliki keberagaman kebudayaan. Keberagaman inilah yang akan memunculkan sifat-sifat tertentu dalam kelompok masyarakat yang ada. Bagi bangsa Indonesia, multikulturalisme adalah suatu keniscayaan dan keharusan. Keragaman suku, bangsa, ras, agama, dan bahasa merupakan ciri khas serta kelebihan bangsa Indonesia yang membedakannya dengan bangsa lain. Keragaman budaya pada masyarakat multikultural memiliki dimensi ganda. Pada sisi positif bisa mengukuhkan persatuan, sementara sisi negatifnya bisa menyebabkan perpecahan.

Kementrian Dalam Negeri pada tahun 2012 mencatat jumlah penduduk Indonesia sebanyak 251.857 .940 juta jiwa, dan tidak kurang dari 30 ribu pulau di Indonesia. Dari jumlah pulau tersebut, sebanyak 13.446 pulau telah diberi nama dan sekitar 17 ribu pulau lainnya masih tanpa nama, dimana mereka tinggal tersebar di pulau-pulau tersebut. Hal ini yang juga berkaitan dengan tingkat peradaban kelompok-kelompok suku bangsa dan masyarakat di Indonesia yang berbeda.

Dalam konteks Indonesia, sebagai salah satu penerapan keberagaman mayarakat dapat dilihat pada proses dan dampak dari berbagai gejolak sosiokultural dan politikyang terjadi. Adanya konflik sektoral dan horizontal mengancam cita-cita kebhinekaan, dan keberagaman bangsa Indonesia.

Masalah pembinaan persatuan dan kesatuan bangsa juga mulai diguncang, upaya tersebut sudah tidak diperlukan lagi setelah bangsa Indonesia merdeka lebih dari 46 tahun, dan bahwa upaya pembinaan itu seolah-olah hanya dalih untuk membatasi gerak masyarakat belaka. Mereka lupa kondisi geografis dan demografis masyarakat Indonesia yang beraneka ragam. Mereka lupa kepada masa silam bangsa Indonesia yang penuh pemberontakan, mereka lupa kepada semboyan Bhinneka Tunggal lka, yang mengamanatkan kepada bangsa Indonesia untuk senantiasa membina persatuan dan kesatuan karena banyak perbedaannya.

Persatuan dan kesatuan Indonesia inilah yang seharusnya menjadi ekspresi dan pendorong semangat kegotongroyongan, serta untuk mewujudkannya perlu diperkuat dengan budaya gotong royong dalam kehidupan masyarakat sipil dan politikdengan mengembangkan pendidikan kewarganegaraan dan multikulturalismeyang mampu membangun rasa keadilan dan kebersamaan. Jika warga negara suatu bangsa 
Indonesia mengingkari sifat multikulturyang sudah ada sejak ratusan tahun lalu, hal itu menyebabkan bangsa Indonesia kembali dihadapkan pada suatu situasi yang meresahkan, yaitu ancaman disintegrasi yang dapat merusak persatuan dan kesatuan bangsa. Melalui etika kebhinnekaan, dalam bingkai kebersamaan bangsa sebagaimana yang diikrarkan oleh para pemuda pada tahun 1928, dapat menjadi ciri maupun orientasi tiap individu masyarakat Indonesia di mana kebersamaan adalah paradigma dari masyarakat lingkungannya.

Meskipun masyarakat Indonesia merupakan masyarakat yang pluralistik dari sisi ras, etnis, bahasa, status sosial, kepercayaan, dan sebagainya, namun merupakan suatu kesatuan guna mencapai tujuan bersama dalam konteks Negara Kesatuan Republik Indonesia (NKRI) yang berdasar Pancasila dan UUD 1945. Artikel ini bertujuan untuk memaknai secara dalam multikulturalisme itu sendri dan merefleksikan penerapan sikap multikultural isme sebagai pentingnya upaya tersebut untuk persatuan dan kesatuan Negara Republik Indonesia yang memiliki keberagaman etnik, agama, dan budaya di dalamnya agar tetap mampu merawat kebhinekaan dan menjaga keindonesiaan, sehingga bisa menjadi contoh bagi warga bangsa lain.

\section{Kasus/Masalah}

Dalam sejarah perjalanan bangsa Indonesia, realitas kehidupan berbangsa dan bernegara telah mengalami pasang surutyang melelahkan dan menguras tenaga. Polemik Natsir-Soekarno pada masa pra kemerdekaan, tentang hubungan agama dan negara adalah satu contoh nyata sebagai sebuah realitas sejarah bangsa ini. Polemik tersebut telah merefleksikan pencarian bentuk jati diri bangsa yang merupakan pertarungan ideologis antara kubu nasional sekuler dan kubu Islam politik yang sampai saat ini masih menjadi perbincangan yang sering muncul dimana-mana. Konflik bisa saja terjadi karena perbedaan pandangan antara dua atau lebih kelompok masyarakat di suatu wilayah. Beberapa konflik mengerikan yang pernah terjadi di Indonesia karena disebabkan perbedaan padangan, yaitu:

1. Tragedi Sampit pada tahun 2001.

Tahun 2001 adalah salah satu sejarah kelam bangsa Indonesia terutama di daerah Sampit. Tragedi Sampit adalah kerusuhan yang amat mengerikan yang melibatkan dua suku Dayak dan suku Madura. Tercatat 500 orang tewas dan 100 orang di antaranya mengalami pemenggalan kepala.

2. Konflik antar agama di Ambon tahun 1999. Konflik ini awalnya dianggap sebagai konflik biasa. Namun muncul sebuah dugaan jikaada pihak yang sengaja merencanakan dengan memanfaatkan isu yang ada. Selain itu ABRI juga tak bisa menangani dengan baik, bahkan diduga sengaja melakukannya agar konflik terus berlanjut dan mengalihkan isu-isubesar lainnya. Kerusuhan yang terjadi di Ambon membuat kerukunan antar umat beragamadi Indonesia jadi memanas hingga waktu yang cukup lama.

3. Konflik antar etnis pada tahun 1998.

Konflik ini diawali oleh krisis moneter yang mengakibatkan sendi-sendi negara lumpuh dan meluas sehingga berubah menjadikonflik antar entis Pribumi dan etnis Tionghoa, konflik ini mengakibatkan banyak aset-aset Tionghoa dijarah dan dibakar. Selain itu, juga banyak laporan yang menyatakan telah terjadi pelecehan seksual dan pembunuhan pun tak bisa dihindari. Konflik antar etnisini benar-benar menjadikan Indonesia seperti lautan darah.

4. Konflik antar golongan dan pemerintah (GAM, RMS dan OPM).

Konflik antar golongan memang sering terjadi di Indonesia, namun yang paling parah adalah perlawanan GAM terhadap pemerintah yang akhirnya dibawa ke dunia Internasional. Konflik ini terjadi didasari atas keinginan memerdekakan diri dari negara Indonesia. Sayangnya pemerintah tidak mengedepankan dialog, sehingga operasi militer pun akhirnya diberlakukan oleh pemerintah selama bertahun-tahun dan telah memakan banyak korban. Konflik ini akhirnya mereda setelah terjadi kesepakatan, yang menjadikan Aceh sebagai daerah dengan otonomi khusus. 


\section{Tinjauan Pustaka}

Multikulturalisme adalah landasan budaya yang terkait dengan pencapaian civility (keadaban), yang amat esensial bagi terwujudnya demokrasi yang berkeadaban, dan keadaban yang demokratis (Azra, 2004).

Ide multikulturalisme merupakan suatu gagasan untuk mengatur keberagaman dengan prinsip-prinsip dasar pengakuan akan keberagaman itu sendiri (politics of recognition). Gagasan ini menyangkut pengaturan hubungan sosial atau relasi antara kelompok etnis (Taylor, 1994: 25).

Multikultural isme adalah sebuahideologi yang mengakui dan mengagungkan perbedaan dalam kesederajatan baik secara individual maupun secara kebudayaan (Suparlan, 2008: 726).

Pendekatan multikultural itu sendiri dilakukan dengan memberikan pendidikan multikultural, yaitu sebuah ikhtiar untuk mengurangi gesekan-gesekan atau ketegangan-ketegangan yang diakibatkan oleh perbedaan-perbedaan dalam masyarakat (Tilaar, 2004:104).

Pancasila sila ke 2 yaitu Kemanusiaan Yang Adil dan Beradab, pada butir ke dua juga memuat tentang perlindungan terhadap keberagaman beragama. Butir ke 2 dari sila tersebut menyatakan bahwa mengakui persamaan derajad, hak dan kewajiban asasi setiap manusia tanpa membeda-bedakan suku, keturunan, agama, jenis kelamin, wama kulit, dan sebagainya.

Undang-Undang Dasar 1945 pasal 28 dan 29 dengan tegas menyatakan tentang keberagaman dan kebebasan hidup beragama. Secara jelas pasal $28 \mathrm{E}$ menyatakan sebagai berikut: ayat (1) Setiap orang bebas memeluk agama dan beribadat menurut agamanya, memilih pendidikan dan pengajaran, memilih pekerjaan, memilih kewarganegaraan, memilih tempat tinggal di wilayah negara dan meninggalkannya, serta berhak kembali. Ayat (2) Setiap orang berhak atas kebebasan meyakini kepercayaan, menyatakan pikiran dan sikap, sesuai dengan hati nuraninya. Ayat (3) Setiap orang berhak atas kebebasan berserikat, berkumpul, dan mengeluarkan pendapat.

\section{Pembahasan}

\section{Konsep Multikulturalisme}

Konsep multikulturalisme bukanlah kosa kata baru bagi sejarah Indonesia. Substansi multikulturalisme lekat kaitannya dengan lahirnya NKRI. Multikulturalisme didefinisikan secara umum oleh banyak kalangan sebagai sebuah kepercayaan yang menyatakan bahwa kelompok-kelompok etnik atau budaya (ethnic and cultural groups) dapat hidup berdampingan secara damai dalam prinsipcoexistence yang ditandai oleh kesediaan untuk menghormati budaya lain.

Multikulturalisme merupakan ideologi yang lahir dari keragaman struktur budaya dalam masyarakat yang membentuk suatu masyarakat yang multikultur. Kehidupan masyarakat multikultural rentan adanya konflik sosial. Oleh karena itu, terbentuklah multikulturalisme sebagai acuan utama terwujudnya kedamaian di tengah keragaman, yang mengakui dan mengagungkan perbedaan dalam kesederajatan baik secara individual maupun secara kebudayaan. Dalam multikulturalisme, sebuah masyarakat dilihat sebagai sebuah kebudayaan yang berlaku umum dalam masyarakat yang coraknya seperti sebuah mozaik. Di dalam mozaik tercakup semua kebudayaan dari masing-masing suku bangsa yang sangat jelas dan belum tercampur oleh warna budaya lain membentuk masyarakat yang lebih besar.

Semangat multikulturalisme adalah mencoba menggugat pertanyaan pokok tentang bagaimana kelompok-kelompoketnik dan budaya itu semestinya memposisikan dirinya ke dalam sebuah kehidupan bersama dalam sebuah masyarakat nasional yang dikelilingi oleh nilai-nilai universal, seperti: demokrasi, keadilan, persatuan, dan kemanusiaan. Lebih jelasnya adalah, bagaimana misalnya kelompok-kelompok etnik Bugis, Makassar, Batak, Minang, Betawi, Sunda, Jawa, China, Bali, Ambon, Manado, Papua atau yang beragama Islam, Hindu, Khong Hu Cu, Buddha, Kristen, Katolik, itu semuanya mampu hidup berdampingan dalam sebuah proses sosial yang di satu pihak memberi tempat bagi terpeliharanya identitas lokal dan kepercayaan partikularnya masing- 
masing, dan di pihak lain memberi kesempatan bagi sebuah proses terjadinya integrasi sosial.

Ide multikulturalisme menurut Taylor (1994: 25) merupakan suatu gagasan untuk mengatur keberagaman dengan prinsipprinsip dasar pengakuan akan keberagaman itu sendiri (politics of recognition). Gagasan ini menyangkut pengaturan hubungan sosial atau relasi antara kelompok etnis. Sedangkan Suparlan (2008: 726) mengungkapkan bahwa multikulturalisme adalah sebuah ideologi yang mengakui dan mengagungkan perbedaan dalam kesederajatan baik secara individual maupun secara kebudayaan. Oleh karena itu, konsep multikulturalisme tidak dapat disamakan dengan konsep keanekaragaman secara suku bangsa (ethnic) atau kebudayaan suku bangsa yang menjadi ciri khas masyarakat majemuk, karena multikulturalisme menekankan etnisitas dalam kesederajatan.

Multikultural isme merupakan paradigma yang baik dalam upaya merajut kembali hubungan antarmanusia yang belakangan selalu hidup dalam suasana penuh konfliktual. Secara sederhana, multikulturalisme dapat dipahami sebagai suatu konsep keanekaragaman budaya dan kompleksitas dalam masyarakat. Melalui multikulturalisme masyarakat diajak untuk menjunjung tinggi toleransi, kerukunan, dan perdamaian bukan konflik atau kekerasan dalam arus perubahan sosial. Meskipun berada dalam perbedaan, paradigma multikulturalisme diharapkan menjadi solusi konflik sosial yang terjadi selama ini. Dengan demikian, inti multikulturalisme adalah kesediaan menerima kelompok lain secara sama sebagai kesatuan, tanpa memedulikan perbedaan budaya, etnis, gender, bahasa, ataupun agama. Sedangkan fokus multikulturalisme terletak pada pemahaman akan hidup penuh dengan perbedaan sosial budaya, baik secara individual maupun kelompok dan masyarakat. Dalam hal ini individu dilihat sebagai refleksi dari kesatuan sosial dan budaya.

\section{Membangun Multikulturalisme}

Ada dua sejarah penting bangsa Indonesia, pertama, adalah Ikrar Sumpah Pemuda pada Tahun 1928 dan kedua, Proklamasi Kemerdekaan Negara Republik Indonesia pada Tahun 1945. Ikrar "Sumpah Pemuda" menegaskan tekad dengan bersumpah untuk berbangsa, bertanah air, dan berbahasa satu yaitu Indonesia. Ketika merdeka para pejuang dan pendiri bangsa ini memilih bentuk negara kesatuan. Kedua peristiwa bersejarah tersebut menunjukkan adanya kebutuhan yang secara sosial dan budaya merefleksi keberadaan multikulturalisme di tanah air. Kenyataan sejarah melalui serangkaian peristiwa sosial dan budaya tersebut lebih diperkuat lagi melalui semboyan "Bhineka Tunggal Ika" yaitu "berbeda-beda dalam kesatuan" pada lambang negara Indonesia.

Multikulturalisme tentu saja memiliki dampak positif dan negatif. Dampak positifnya bisa mengukuhkan persatuan, sementara dampak negatifnya bisa menyebabkan perpecahan. Saat ini, Indonesia sedang diuji dengan adanya ancaman akan keberadaan multikulturalisme. Dalam masyarakat banyak muncul sifat atau sikap egosentrisme, baik atas nama agama, suku, atau politik. Sifat atau sikap tersebut dapat berubah menjadi eksklusivisme dan pada akhirnya memicu perpecahan, apalagi jika ditambah dengan himpitan masalah ekonomi, sosial, serta budaya.

Salah satu tantangan rakyat Indonesia saat ini adalah bagaimana menjadikan multikulturalisme itu sebagai kekuatan, yang tentunya nanti bisa membawa rakyat pada persatuan dan kesatuan bangsa. Multikulturalisme masyarakat Indonesia dapat menimbulkan masalah tentang sulitnya membangun masyarakat Indonesia yang terintegrasi pada tingkat lokal dan tingkat nasional. Salah satu masalah yang ada dalam masyarakat terkait multikulturalisme adalah konflik yang dapat memecah persatuan dan kesatuan dalam masyarakat. Oleh karena itu dibutuhkan strategi pemerintah untuk menghindari perpecahan akibat dampak negatif multikulturalisme. 
Menurut Din Syamsudin selaku Presiden Komite Keagamaan dan

Perdamaian Asia dalam acara World

Culture Forum (WCF) 2016 yang diselenggarakan pada tanggal 12 Oktober 2016 di Nusa Dua Bali, bahwa untuk membangun persatuan melalui multikulturalisme, pertama, harus ada kesadaran tentang pentingnya multikulturalisme, yang dalam pandangan Islam adalah hukum (ketetapan) Tuhan, dan kedua, mengembangkan budaya dalam masyarakat untuk saling menghargai dan tenggang rasa. Memang ada perbedaan di antara kelompok masyarakat, tetapi di sisi lain, juga ada persamaan, oleh karena itu penting mencari titik temunya. Indonesia sangat beruntung karena pendiri bangsa ini telah mewariskan dua pedoman yang bisa menyatukan kemajemukan dalam masyarakat, yakni Pancasila dan Bhinneka Tunggal Ika. Perlu semangat kebersamaan, kerjasama, dan berbagi atas nama kemanusiaan tanpa memandang perbedaan untuk menguatkan persatuan di antara masyarakat dengan budaya yang beragam.

Menurut Magnis-Suseno (2005: 216), bangsa Indonesia yang multikultur mutlak harus dipandang dari kacamata multikulturalisme, Indonesia hanya dapat bersatu, bila pluralitas yang menjadi kenyataan sosial dihormati. Artinya, penegakan kesatuan Indonesia bukan hendak menghilangkan identitas setiap komponen bangsa, tetapi harapannya agar semuanya menjadi warga negara Indonesia tanpa merasa terasing. Sikap saling menghormati identitas masingmasing dan kesediaan untuk tidak memaksakan pandangan sendiri tentang "yang baik" kepada siapapun merupakan syarat keberhasilan masa depan Indonesia. Untukitu, diperlukan transformasi kesadaran multikulturalisme menjadi identitas nasional, integrasi nasional, dan menempatkan agama menjadi fondasi kesatuan bangsa.

Dengan adanya struktur masyarakat Indonesia dan masalah multikultural, maka diperlukan kebijakan pemerintah yang menjamin kelangsungan hidup masyarakat, dengan cara tetap menghormati pranata, struktur, dan kebiasaan yang ada (social sustainability). Indonesia yang multikultural ini akan tetap bertahan sebagai sebuah negara kesatuan, apabila elemen-elemen pendukung kebersamaan tetap dipertahankan. Kecenderungan dominasi mayoritas (suku dan agama) harus ditata kembali agar rasa memiliki bangsa ini tidak luntur. Gejolak yang terjadi di berbagai daerah seperti Aceh, Sulawesi Tengah, Kalimantan Tengah, Maluku, dan Papua, membutuhkan penanganan yang serius. Kelalaian tidak memperhatikan multikultural bangsa, dimasa mendatang akan menjadi bom waktu yang sangat mengganggu persatuan dan kesatuan bangsa.

Konflik antar-suku bangsa dewasa ini disebabkan antara lain tidak ada atau kurangnya pemahaman dan penghargaan atas suku bangsa lain, sehingga salah satu usaha untuk menanggulangi konflik ini adalah dengan usaha melakukan sosialisasi atau pembinaan kepada masyarakat tentang pentingnya menjaga keserasian antara suku bangsa. Karena salah satu keuntungan ini adalah bisa menjadikan identitas suatu bangsa. Pembinaan kepada masyarakat dapat dilakukan dengan sosial isasi langsung kepada masyarakat umum maupun melalui pendidikan di sekolah, khususnya kepada generasi pemimpin bangsa. Melalui pendidikan kita dapat mengubah cara berpikir kita dengan pandangan yang lebih baik demi terciptanya lingkungan sosial yang harmonis.

\section{Kesimpulan}

Multikulturalisme merupakan sebuah paradigma dalam menjaga keharmonisan hubungan antaretnik yang tidak saja perludan penting, tetapi juga merupakan jawaban atas kegagalan kita di masa lalu dalam mengelola masyarakat majemuk di Indonesia. Perbedaan merupakan keniscayaan yang mesti dan harus diterima oleh semua kelompok etnis di tanah air. Dalam konteks bernegara, berbangsa, dan bermasyarakat akan menimbulkan keragaman tatanan sosial dan kebudayaan. 


\section{Daftar Pustaka}

Siyoto, S., \& Sodik, M. A. (2015). Dasar metodologi penelitian. Literasi Media Publishing.

Sodik, MA, \& Nzilibili, SMM (2017). Peran Promosi Kesehatan Dan Dukungan Keluarga Dengan Sikap Pasangan Usia Subur Dalam Mengikuti Program Keluarga Berencana Di Bidang Kesehatan. Jurnal Penelitian Global Kesehatan Masyarakat , 2 (2), 82-89.

Sodik, MA, Suprapto, SI, \& Pangesti, D. (2013). Faktor-Faktor Yang Berhubungan Dengan Pelaksanaan Pelayanan Prima Pegawai Di RSui Orpeha Tulungagung. STRADA Jurnal IImiah Kesehatan , 2 (1), 24-32.

Sodik, M. A. (2018). Merokok \& Bahayanya.

Sodik, MA, \& Setyani, AT (2018). Pengaruh Merokok Bagi Remaja Terhadap Perilaku dan Interaksi Sosial.

Suparlan, P. (2014). Menuju masyarakat Indonesia yang multikultural. Antropologi Indonesia.

Nisrina, A., \& Nurani, F. Multikulturalisme Dalam Bingkai Persatuan dan Kesatuan Negara Republik Indonesia.

Mulyadi, M. (2017). Membangun NKRI dengan Multikulturalisme. Majalah Info Singkat:Kesejahteraan Sosial, IX, 10.

Ambarudin, R. I. (2016). Pendidikan multikultural untuk membangun bangsa yang nasionalis religius. Jurnal Civics, 13(1), 28-45. 